\title{
Results of paclitaxel (day I and 8) and carboplatin given on every three weeks in advanced (stage III-IV) non-small cell lung cancer Perran F Yumuk*1, Nazim S Turhal ${ }^{1}$, Mahmut Gumus ${ }^{2}$, Nilgun F Hatabay ${ }^{3}$, Orhan Turken ${ }^{4}$, Alper Ozkan², Taflan Salepci², Mehmet Aliustaoglu ${ }^{2}$ and Rengin Ahiskali ${ }^{5}$
}

\author{
Address: ${ }^{1}$ Division of Medical Oncology, Marmara University Hospital, Tophanelioglu C. 13/15 Altunizade, Uskudar, Istanbul 81190 Turkey, \\ ${ }^{2}$ Oncology Unit, Dr. Lutfi Kirdar Research and Training Hospital, Kartal, Istanbul, Turkey, ${ }^{3}$ Oncology Unit, SSK Sureyyapasa Chest and \\ Cardiovascular Diseases Hospital, Maltepe, Istanbul 34854 Turkey, ${ }^{4}$ Division of Medical Oncology, Gulhane Military Medical Academy, \\ Acibadem, Uskudar, Istanbul, Turkey and ${ }^{5}$ Department of Pathology, Marmara University Hospital, Tophanelioglu C. 13/15 Altunizade, Uskudar, \\ Istanbul 81190 Turkey \\ Email: Perran F Yumuk* - fuldenyumuk@superonline.com; Nazim S Turhal - turhal@superonline.com; \\ Mahmut Gumus - mgumus@superonline.com; Nilgun F Hatabay - fuldenyumuk@superonline.com; Orhan Turken - oturken@hotmail.com; \\ Alper Ozkan - mgumus@superonline.com; Taflan Salepci - mgumus@superonline.com; \\ Mehmet Aliustaoglu - smaliustaoglu@superonline.com; Rengin Ahiskali - fuldenyumuk@superonline.com \\ * Corresponding author
}

Published: 25 January 2005

BMC Cancer 2005, 5:10 doi:10.1186/147/-2407-5-10
Received: 30 June 2004

Accepted: 25 January 2005

This article is available from: http://www.biomedcentral.com/I47/-2407/5/10

(C) 2005 Yumuk et al; licensee BioMed Central Ltd.

This is an Open Access article distributed under the terms of the Creative Commons Attribution License (http://creativecommons.org/licenses/by/2.0), which permits unrestricted use, distribution, and reproduction in any medium, provided the original work is properly cited.

\begin{abstract}
Background: Both paclitaxel $(\mathrm{P})$ and carboplatin $(\mathrm{C})$ have significant activity in non-small cell lung cancer (NSCLC). The weekly administration of $P$ is active, dose intense, and has a favorable toxicity profile. We retrospectively reviewed the data of 5 I consecutive patients receiving $C$ and day I and 8 P chemotherapy (CT) regimen in advanced stage NSCLC to evaluate the efficacy and toxicity.

Methods: Patients treated in our institutions having pathologically proven NSCLC, no CNS metastases, adequate organ function and performance status (PS) ECOG 0-2 were given P I I $2.5 \mathrm{mg} / \mathrm{m}^{2}$ intravenously (IV) over I hour on day I and 8, followed by C AUC 5 IV over I hour, repeated in every three weeks. PC was given for maximum of 6 cycles.

Results: Median age was 58 (age range 39-77) and 4 I patients (80\%) were male. PS was 0/I/2 in 29/17/5 patients and stage was IIIA/IIIB/IV in 3/I4/34 patients respectively. The median number of cycles administered was 3 (I6). Seven patients (14\%) did not complete the first 3 cycles either due to death, progression, grade 3 hypersensitivity reactions to $P$ or lost to follow up. Best evaluable response was partial response (PR) in $45 \%$ and stable disease (SD) in $18 \%$. Twelve patients (24\%) received local RT. Thirteen patients (25\%) received 2 nd line CT at progression. At a median follow-up of 7 months (range, I-20), 25 (49\%) patients died and 35 patients (69\%) progressed. Median overall survival (OS) was II \pm 2 months ( $95 \%$ Cl; 6 to I6), I-year OS ratio was $44 \%$. Median time to progression (TTP) was $6 \pm$ I months (95\% Cl; 4 to 8), I-year progression free survival (PFS) ratio was $20 \%$. We observed following grade 3 toxicities: asthenia (10\%), neuropathy $(4 \%)$, anorexia (4\%), anemia (4\%), hypersensitivity to $\mathrm{P}(2 \%)$, nausea/vomiting $(2 \%)$, diarrhea $(2 \%)$ and neutropenia $(2 \%)$. Two patients $(4 \%)$ died of febrile neutropenia. Doses of CT were reduced or delayed in 12 patients (24\%).
\end{abstract}

Conclusions: $\mathrm{P}$ on day $\mathrm{I}$ and 8 and $\mathrm{C}$ every three weeks is practical and fairly well tolerated outpatient regimen. This regimen seems to be comparably active to regimens given once in every three weeks. 


\section{Background}

Lung cancer is the leading cause of cancer related deaths all around the world. About $80 \%$ of all lung cancers are non-small cell lung cancer (NSCLC) and more than 50\% of these patients present with locally advanced or metastatic disease.

Meta-analysis of several randomized trials have demonstrated a modest survival advantage for treatment with cisplatin-based regimens in patients with advanced stages of NSCLC [1,2]. Furthermore, chemotherapy (CT) also has been shown to ameliorate symptoms and increase quality of life [3]. Addition of second generation CT regimens with cisplatin or carboplatin plus newer agents, such as taxanes (paclitaxel and docetaxel), gemcitabine, vinorelbine have shown increased response rates and 1-year survival ratios, but overall survivals have not been altered [46].

Being the first of the taxane antimicrotubule agents, paclitaxel $(P)$ demonstrated overall response rates of $21-24 \%$ and 1 -year survival rates of $37-42 \%$ in the phase II trials where it was used as a single agent $[7,8]$. Antiangiogenic effect of P has also been reported (9). Carboplatin (C) has also demonstrated comparable activity but better toxicity profile than cisplatin in the treatment of advanced NSCLC $[10,11]$.

$\mathrm{P}$ and $\mathrm{C}$ used in combined chemotherapy regimens have significant activity in NSCLC. PC given every three weeks is considered to be one of the standard regimens being used worldwide [10]. The weekly administration of $P$ is active, dose intense, and has a favorable toxicity profile. To evaluate the efficacy and toxicity of $\mathrm{C}$ and day 1 and 8 $P$ in advanced stage NSCLC, we retrospectively reviewed 51 consecutive patients receiving this CT regimen.

\section{Methods}

All patients with stage III or IV NSCLC treated at Medical Oncology Units of Marmara University Hospital, Dr. Lutfi Kirdar Research and Training Hospital, SSK Sureyyapasa Chest and Cardiovascular Diseases Hospital and Gulhane Military Medical Academy Hospital within July 2002 and August 2003 were considered for this protocol. Eligible patients were required to have pathologically proven NSCLC, stage III or IV disease at presentation or progressed after surgery, performance status (PS) ECOG 0-2, objective measurable disease, adequate bone marrow functions (white blood cell count $\geq 3500 / \mathrm{mm}^{3}$, hemoglobin $\geq 9 \mathrm{~g} / \mathrm{dl}$, and platelet count $\geq 100000 / \mathrm{mm}^{3}$ ), and adequate liver functions (bilirubin $\leq 1.5 \mathrm{mg} / \mathrm{dl}$ and alanine aminotransferase $\leq 2$ times upper limit of normal and $\leq 5$ times upper limit of normal for the patients with liver metastases) and kidney functions (creatinine $\leq 1.5$ $\mathrm{mg} / \mathrm{dl}$ ). No prior chemotherapy or radiotherapy (except to bone metastases for palliation) was allowed. Patients presenting with known central nervous system (CNS) disease and uncontrolled cardiac arrhythmia were excluded from this study and they were treated with other chemotherapy regimens (single agent or combination of platinum and vinorelbine, docetaxel or gemcitabine).

Patients were treated with P $\left(112.5 \mathrm{mg} / \mathrm{m}^{2} /\right.$ day $)$ on days 1 and 8 , followed by $\mathrm{C}$ (AUC $5 / 6$ ) on day 1 , repeated in every three weeks. Both drugs were diluted in $250 \mathrm{ml}$ of normal saline and given intravenously (IV) over 1 hour. No growth factors were administered. Anti-allergic premedication included IV diphenhydramine $50 \mathrm{mg}$, IV ranitidine $50 \mathrm{mg}$, and IV dexamethasone $16 \mathrm{mg} 1$ hour prior to $\mathrm{P}$ administration.

Toxicity evaluation and routine physical examination were performed in every 3 weeks. Complete blood count (CBC) was done on days 1 and 8 of each cycle, liver and kidney function tests on every 2 cycles. Cranial computed tomography scans (CT), magnetic resonance imaging (MRI) and bone scans were performed as clinically indicated. Side effects of the treatment were graded according to the National Cancer Institute Common Toxicity Criteria (CTC), version 2.0 [12]. Colony stimulating factors were not used.

Response was evaluated with CT of chest and/or abdomen on every $3^{\text {rd }}$ cycle and standard World Health Organization (WHO) criteria were used to determine response [13]. Independent of the stage at presentation, patients having partial response (PR), stable disease (SD) or progressive disease (PD) during CT were consulted for radiotherapy (RT) for either primary treatment or palliation. The treatment was stopped for patients with PD. Patients with CR, PR or SD after 3 cycles continued their treatment. $\mathrm{PC}$ was given for maximum of 6 courses to the patients having PR or SD.

Patients were irradiated with CT based treatment planning and multiple fields arrangements with custom blocking to all fields and involved hilar and mediastinal lymph nodes up to 40-41.4 Gy. Boost was given to the primary tumor. Total dose of 60-61.2 Gy was administered in 1.8-2 Gy daily fractions for 5 days a week and completed in 6 weeks.

\section{Statistical analysis}

Overall survival (OS) and time to progression (TTP) were assessed from the date of diagnosis to the date of death (any cause) and the date of objective disease progression (death was considered a progression event in patients who died before disease progression), respectively. Survival rates were calculated by using the Kaplan-Meier method [14]. The pre-specified prognostic value of age $(<$ 
Table I: Patient characteristics

\begin{tabular}{|c|c|c|}
\hline Characteristics & Number of patients & Percentage (\%) \\
\hline \multicolumn{3}{|l|}{ Age, years } \\
\hline Median & 58 & \\
\hline Range & $(39-77)$ & \\
\hline \multicolumn{3}{|l|}{ Gender } \\
\hline Male & 41 & 80 \\
\hline Female & 10 & 20 \\
\hline \multicolumn{3}{|l|}{ Performance Status } \\
\hline 0 & 29 & 57 \\
\hline I & 17 & 33 \\
\hline 2 & 5 & 10 \\
\hline \multicolumn{3}{|l|}{ Stage } \\
\hline IIIA & 3 & 6 \\
\hline IIIB & 14 & 27 \\
\hline IV & 34 & 67 \\
\hline \multicolumn{3}{|l|}{ Histology } \\
\hline Adenocarcinoma & 16 & 31 \\
\hline Squamous cell carcinoma & 18 & 36 \\
\hline NSCLC & 17 & 33 \\
\hline \multicolumn{3}{|l|}{ Sites of metastases } \\
\hline Lung & 17 & 50 \\
\hline Adrenal & 10 & 29 \\
\hline Bone & 7 & 21 \\
\hline Liver & 7 & 21 \\
\hline Distant LAP & 3 & 9 \\
\hline \multicolumn{3}{|l|}{ Number of metastatic organs } \\
\hline I & 24 & 71 \\
\hline 2 & 9 & 26 \\
\hline 3 & I & 3 \\
\hline \multicolumn{3}{|l|}{ Smoking history } \\
\hline Yes & 42 & 82 \\
\hline No & 9 & 18 \\
\hline
\end{tabular}

60 years vs. $\geq 60$ years), gender, PS ( 0 vs. $1-2$ ), histology (adenocarcinoma vs. squamous cell vs. NSCLC), stage (III vs. IV), smoking history (present vs. absent), and response after third cycle of CT (PR vs. other) were evaluated in univariate and multivariate analyses. Log rank test was used for univariate survival analysis [15]. The multivariate Cox proportional hazard model was applied to identify the variables that can independently influence survival.

\section{Results}

The data of 51 patients receiving PC treatment were collected retrospectively between July 2002 and November 2003. Median follow-up time was 7 months (range, 120). Median age was 58 years (range $39-77$ ) and $45 \%$ of
Table 2: Response rates and second line treatments with CT and RT

\begin{tabular}{lcc}
\hline & Number of patients & Percentage (\%) \\
\hline $\begin{array}{l}\text { Number of PC received } \\
\text { I }\end{array}$ & 2 & 4 \\
2 & 5 & 10 \\
3 & 20 & 39 \\
4 & 3 & 6 \\
5 & 3 & 6 \\
6 & 18 & 35 \\
\hline Response to PC & & \\
PR & & 45 \\
SD & 23 & 18 \\
PD & 9 & 31 \\
Not assessed & 16 & 6 \\
\hline Second line CT & 3 & \\
G \pm Cis / C & 13 & 78 \\
Other & 10 & 23 \\
\hline Local RT & 3 & \\
Stage IIIA & 12 & 25 \\
Stage IIIB & 3 & 42 \\
Stage IV & 5 & 33 \\
\hline
\end{tabular}

CT: Chemotherapy; RT: Radiotherapy; P: Paclitaxel; C: Carboplatin; G: Gemcitabine; Cis: Cisplatin

patients were 60 year-old or above. Eighty percent were male. PS was 0 in $57 \%$ of patients and $67 \%$ had presented with stage IV disease. Most frequent metastatic sites were the other lung (17), adrenal (10), liver (7) and bone (7). Eighty-two percent of the patients had smoking history, median of which was 40 pack-years (range, 0-135). Patients' baseline characteristics are presented in Table 1.

The median number of cycles administered was 3 (range, $1-6)$. Seven patients $(14 \%)$ did not complete the first 3 cycles either due to death (2), progression (3), grade 3 hypersensitivity reaction to $\mathrm{P}(1)$ or lost to follow up (1).

Best evaluable response was PR in $45 \%$ and SD in $18 \%$. Only 22 (43\%) patients continued the treatment after the 3 rd course. At the end of treatment of these 22 patients 10 (46\%) had PR and $6(27 \%)$ had SD, but the other 6 patients $(27 \%)$ had PD. No complete remission was seen. Twelve patients $(24 \%)$ received local RT and 4 of these patients were given low dose gemcitabine $(75 \mathrm{mg} / \mathrm{m} 2 /$ week $\times 5-6$ weeks) as radiosensitizing agent. Of these 12 patients 3 presented with stage IIIA and all had PR to PC therapy. But of the 5 patients with IIIB disease who were irradiated only one patient had PR, 3 had SD and another one had PD after the 3 cycles of CT. Four patients with 


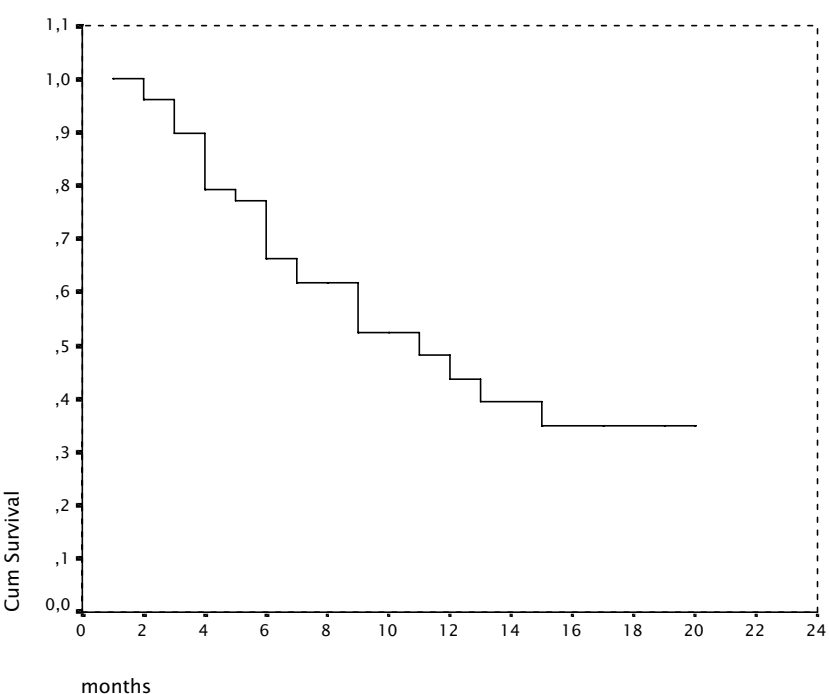

Figure I

Overall survival Kaplan-Meier curve

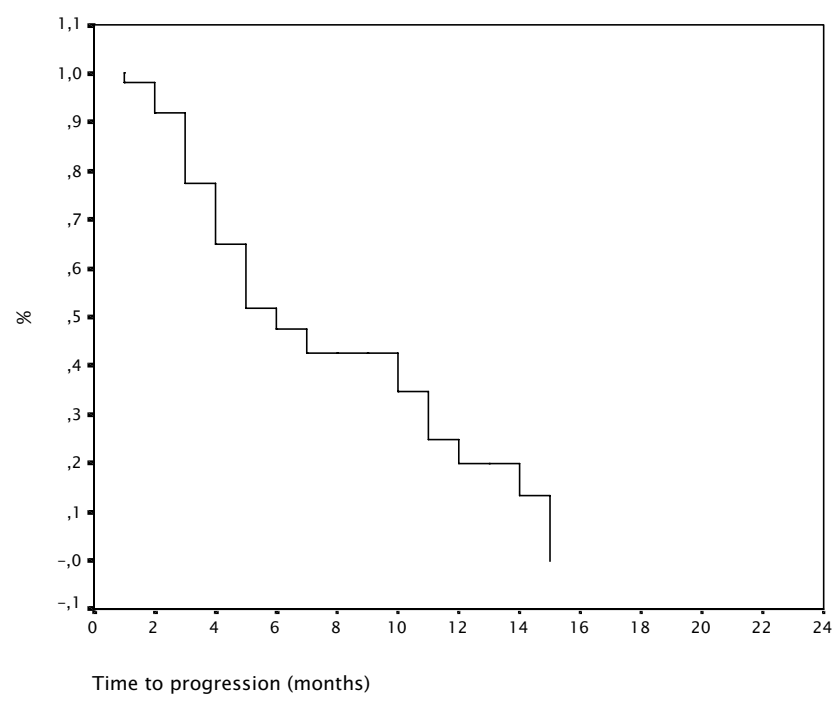

Figure 2

Progression free survival curve

stage IV were offered RT for palliation. Thirteen patients $(25 \%)$ received 2 nd line CT at progression and of those only one patient had PR and another SD to this treatment. For 2nd line CT gemcitabine \pm cisplatin or $\mathrm{C}$ was used in 10 patients $(78 \%)$ and the rest received other agents like vinorelbine, $\mathrm{C}$ or docetaxel. Details of this data can be seen in Table 2.
At a median follow-up of 7 months 25 (49\%) patients died and 35 patients $(69 \%)$ progressed. Median OS time was $11 \pm 2$ months (95\% CI; 6 to 16), 1-year OS ratio was $44 \%$ (Figure 1). Median TTP was $6 \pm 1$ months (95\% CI; 4 to 8 ), 1-year progression free survival (PFS) ratio was 20\% (Figure 2).

The most frequent toxicity related symptoms were asthenia $(61 \%)$, neuropathy $(42 \%)$ and anorexia (35\%). We observed the following grade 3 toxicities: asthenia (10\%), neuropathy $(4 \%)$, anorexia $(4 \%)$, anemia $(4 \%)$, hypersensitivity to $\mathrm{P}(2 \%)$, nausea/vomiting $(2 \%)$, diarrhea $(2 \%)$ and neutropenia (2\%). Two patients $(4 \%)$ died of febrile neutropenia due to a three day delay in referral to hospital after the onset of fever $>38^{\circ}$, although they were warned about the side effects of the therapy. Doses of CT was reduced or delayed in 12 patients (24\%) (Table 3).

Univariate analysis showed that patients presenting with PS of 0 , stage III disease and having PR after the 3rd cycle of PC have statistically higher OS ( $p=0.015, p=0.018$ and $\mathrm{p}=0.047$, respectively)(Table 4). PS and stage of the disease at presentation and response to the CT after the 3rd cycle were also statistically significant independent prognostic factors influencing the OS in multivariate Cox regression analysis $(\mathrm{p}=0.034, \mathrm{p}=0.049$ and 0.021, respectively).

\section{Discussion}

Paclitaxel and carboplatin have been shown to be an effective and well tolerated CT regimen in advanced stage NSCLC [10]. PC given once in every three weeks is one of the most widely used standard schedules worldwide based on the spectrum of activity and the ease of administration. This regimen results in an objective response rate of $17-25 \%$ with a median survival time of 8 months in stage IIIB and IV NSCLC patients. The major toxicities of this regimen are neuropathy and neutropenia $[10,16]$.

Weekly $\mathrm{P}$ is a relatively new strategy for lowering toxicity and increasing dose-intensity and possibly efficacy. Alvarez et al. have used weekly $\mathrm{P}$ on patients who progressed or remained stable on P administered in every three weeks and reported that it can induce response in $62.5 \%$ of patients with low toxicity [17]. Akerley has also studied weekly $\mathrm{P}$ administration on phase I and phase II settings [18-20]. They started with a P dose of $175 \mathrm{mg} / \mathrm{m}^{2} /$ week $\times$ 6 every 8 weeks in the phase II trial, but they had to reduce the dose up to $50 \%$ due to primarily neutropenia and neuropathy with extended therapy. Therefore, they recommended $150 \mathrm{mg} / \mathrm{m}^{2}$ as the weekly dose of P [20].

Weekly dose of $\mathrm{P}$ in combination with cisplatin or $\mathrm{C}$ had been administered in NSCLC patients by Belani et al. $[21,22]$. They used this combination in a multicenter 
Table 3: Toxicities seen during PC treatment

\begin{tabular}{|c|c|c|c|c|}
\hline Toxicity & Overall (\%) & Grade I-2 (\%) & Grade 3 (\%) & Grade 4 (\%) \\
\hline Neutropenia & 12 & 10 & 2 & \\
\hline Febrile neutropenia & 4 & & & 4 \\
\hline Anemia & 22 & 18 & 4 & \\
\hline Asthenia/Fatigue & 61 & 51 & 10 & \\
\hline Neuropathy & 42 & 38 & 4 & \\
\hline Anorexia & 35 & 31 & 4 & \\
\hline Arthralgia & 31 & 31 & & \\
\hline Nausea/Vomiting & 22 & 20 & 2 & \\
\hline Diarrhea & 8 & 6 & 2 & \\
\hline Mucositis & 6 & 6 & & \\
\hline Hypersensitivity to $P$ & 2 & & 2 & \\
\hline
\end{tabular}

Table 4: Prognostic factors in the univariate analyses for overall survival

\begin{tabular}{|c|c|c|}
\hline Variables & Median OS (months) & $\mathrm{P}$ \\
\hline \multicolumn{3}{|l|}{ Age } \\
\hline 60 years and over & $11 \pm 2$ & 0.87 \\
\hline Less than 60 years & $12 \pm 3$ & \\
\hline \multicolumn{3}{|l|}{ Gender } \\
\hline Male & $9 \pm 3$ & 0.22 \\
\hline Female & $15 \pm 6$ & \\
\hline \multicolumn{3}{|l|}{ PS } \\
\hline 0 & $15 \pm 3$ & $0.015^{*}$ \\
\hline $\mathrm{I}-2$ & $6 \pm 2$ & \\
\hline \multicolumn{3}{|l|}{ Histology } \\
\hline Adenocarcinoma & $15 \pm 5$ & 0.73 \\
\hline Squamous cell & $13 \pm 7$ & \\
\hline NSCLC & $11 \pm 3$ & \\
\hline \multicolumn{3}{|l|}{ Stage at presentation } \\
\hline III & NRt & $0.018^{*}$ \\
\hline IV & $9 \pm 2$ & \\
\hline \multicolumn{3}{|l|}{ Smoking history } \\
\hline Yes & $9 \pm 2$ & 0.20 \\
\hline No & NRt & \\
\hline \multicolumn{3}{|c|}{ Response after 3 cycles of CT } \\
\hline PR & $13 \pm 2$ & $0.047 *$ \\
\hline Other & $6 \pm 1$ & \\
\hline
\end{tabular}

* Statistically significant

+ Mean OS is $15 \pm 2$ months

PS: ECOG Performance status; NR: Not reached; CT: Chemotherapy

three arm trial in 401 patients with stage IIIB and IV disease [21]. In that trial $P$ was given $100 \mathrm{mg} / \mathrm{m}^{2} /$ week for 3 weeks out of 4 week cycles in arms I and II, with $\mathrm{C}$ either AUC of 6 on day 1 or AUC of 2 on days 1, 8 and 15 of each of four 4-week cycles. Arm III of this trial consisted of P $\left(150 \mathrm{mg} / \mathrm{m}^{2}\right)$ and $\mathrm{C}(\mathrm{AUC}=2)$ given weekly for 6 out of 8 weeks for a total of two cycles. Greater percentage of the patients on arm I received intended CT (30\% of P and
$55 \%$ of C) compared with the other arms (28-29\% of $\mathrm{P}$ and $21-22 \%$ of $\mathrm{C}$ ). Patients on arm I received more than half of the planned $\mathrm{C}$ dose. The main reasons for discontinuation of therapy were progression of disease $(31 \%)$ and adverse events (15\%). Median time to progression and median survival time were significantly higher for arm I than arm II for patients with stage IIIB disease. Performance status of the patients was also statistically related to the survival times. Patients with PS-0/1 had longer median PFS with treatment arm I than arm II and patients with PS-2 had higher median OS with arm I than arm II. Although arm I was the most easily tolerable schedule between the three arms, grade 3 or 4 neutropenia was observed in $22 \%$ of the patients included. In this trial treatment arm I had a response rate of $32 \%$, median TTP of 6.9 months, median OS time of 11.3 months and 1year survival rate of $47 \%$. In our study, response rate was 45\%, median TTP was 6 months, median OS time was 11 months and 1-year survival rate was $44 \%$. The majority of our patients comprised of stage IIIB and IV disease, similar to the patient group in Belani's study resulting in similar response rates and survival data [21]. These results also seem more effective than the regimen given once in every three weeks of the same drugs $[10,16]$.

We used the standard dose of $\mathrm{P}\left(225 \mathrm{mg} / \mathrm{m}^{2}\right)$ given in every three weeks and divided into two consecutive weeks. $\mathrm{C}$ dose was calculated according to Calvert formulation with an AUC of 5. This is a lower dose than the dose of $\mathrm{C}$ being used in other phase III trials in the literature. In our study only 4 patients ( $8 \%$ ) had dose reduction of $10 \%$ and $16 \%$ of patients had treatment delays of 1 week because of side effects. According to this data, $76 \%$ of patients have received the total planned doses of the drugs on scheduled date. Two patients (4\%) died of febrile neutropenia due to a three day delay in referral to hospital after the onset of fever $>38^{\circ}$, although they were warned about the side effects of the therapy. It is worth mention- 
ing that none of our patients received any colony stimulating factors.

We have shown that the response to treatment after the third cycles of CT was one of the independent prognostic factors influencing OS. It has already been reported by Socinski et al. that 4 cycles of CT give the maximum benefit which could be obtained from CT in patients with stage IIIB and IV NSCLC [23]. Smith et al. also studied 3 cycles versus 6 cycles of CT in the same group of patients and failed to show any survival advantage for longer treatment durations [24]. In addition, there was an increase in the side effects such as fatigue, nausea and vomiting in the patients receiving six courses.

It has been shown that PC combination has relatively mild toxicity profile. Belani et al. observed in their phase I trial that patients who received the PC combination in every three weeks experienced less severe thrombocytopenia than would be expected from $\mathrm{C}$ alone. In the view of this finding they suggested that there was a platelet-sparing effect of $\mathrm{P}$ on the dose-limiting thrombocytopenia side effect of $C$ [25]. This phenomenon was also shown by Akerley [18] and Kearns [26]. Akerley reported that platelet counts rose by $17000 / \mathrm{mL} /$ week with weekly P administration [18]. Belani also speculated on the mechanism for this platelet protective effect and said that it may involve some alteration of megakaryocytopoiesis or thrombocytopoiesis, which could result in increased levels of endogenous thrombopoietin or other cytokines [27]. Kearns et al. suggested that prior exposure to P may suppress the inhibition of platelet formation, which is associated with C [26]. None of our patients experienced thrombocytopenia during our CT treatment with day 1 and $8 \mathrm{P}$ with day $1 \mathrm{C}$ on every three weeks.

One of the most frequent side effects during our treatment was neuropathy, but it was usually mild (Grade 1 or 2), only $4 \%$ of our patients experiencing grade 3 sensory neuropathy. Grade 3 or 4 neuropathy has been reported to be $10-20 \%$ in schedules given every three weeks $[10,16]$. Belani reported $3-13 \%$ of grade 3 or 4 neuropathy, but the incidence was lower for arms 1 (P given weekly and $\mathrm{C}$ every four weeks) and 2 (P and $\mathrm{C}$ both given weekly), at only $5 \%$ and $3 \%$, respectively [21]. This result for arm 1 is similar to the neuropathy rate in our study.

Besides the reduced toxicity, weekly administration of $\mathrm{P}$ also increases the drugs' anti-angiogenic and apoptotic effects. The metronomic schedule of $\mathrm{P}$ has been studied widely during the last few years. $P$ had been shown to inhibit endothelial cell proliferation, motility, invasiveness, and cord formation both in vitro and in vivo Matrigel assays in a dose dependent manner [9]. Belani et al. randomized the patients having objective response to weekly $\mathrm{P}$ and $\mathrm{C}$ regimens into two arms (maintenance and observation arms). Patients were either treated with weekly P $\left(70 \mathrm{mg} / \mathrm{m}^{2} /\right.$ week $\times 3$ weeks out of four weeks cycles) in maintenance arm or observed until disease progression has occurred. They reported that the maintenance arm was compared to the observation arm and had a median PFS of 38 weeks vs. 29 weeks, median OS of 75 weeks vs. 60 weeks, respectively [21]. Although there was not a statistically significant difference between the two arms, authors concluded that this might be a result of low number of patients enrolled in the study (only 65 patients in each arm). It is not yet known whether these responses have an anti-angiogenic basis, or whether such responses will translate into a significant prolongation of survival.

Although our study is a retrospective analysis, it is one of the few manuscripts on this PC scheduling in NSCLC in the literature.

\section{Conclusions}

Paclitaxel on day 1 and 8 and carboplatin every three weeks is a practical and fairly well tolerated outpatient regimen. This regimen seems to be comparably active to regimens given every three weeks. This schedule needs to be further evaluated by well planned randomized phase III trials where it could be compared to the standard regimens in patients with advanced stage NSCLC.

\section{Competing interests}

The author(s) declare that they have no competing interests.

\section{Authors' contributions}

PFY designed the study, followed the patients, collected the data, performed the statistical analysis and drafted the manuscript. NST followed the patients and helped with the manuscript. MG followed the patients and helped with statistical analysis. NFH, OT, AO, TS, MA followed the patients. RA confirmed the diagnosis. All authors read and approved the final manuscript.

\section{References}

I. Grilli R, Oxman AD, Julian JA: Chemotherapy for advanced nonsmall-cell lung cancer: How much benefit is enough? J Clin Oncol 1993, II:1866-1872.

2. Non-Small Cell Lung Cancer Collaborative Group: Chemotherapy in non-small cell lung cancer: A meta-analysis using updated data on individual patients from 52 randomized clinical trials. BMJ 1995, 31 I:899-909.

3. Billingham LJ, Cullen $\mathrm{MH}$ : The benefits of chemotherapy in patient subgroups with unresectable non-small-cell lung cancer. Ann Oncol 200I, I 2:167I-1675.

4. Ramanathan RK, Belani CP: Chemotherapy for non-small cell lung cancer: Past, present and future. Semin Oncol 1997, 24:I-I5.

5. Bonomi P, Kim KM, Fairclough D, Cella D, Kugler J, Rowinsky E, Jiroutek $M$, Johnson D: Comparison of survival and quality of life in advanced non-small-cell lung cancer patients treated with two dose levels of paclitaxel combined with cisplatin versus 
etoposide with cisplatin: Results of an Eastern Cooperative Oncology Group Trial. J Clin Oncol 2000, 18:623-63I.

6. Cardenal F, Lopez-Cabrerizo MP, Anton A, Alberola V, Massuti B, Carrato A, Barneto I, Lomas M, Garcia M, Lianes P, Montalar J, Vadell C, Gonzalez-Larriba JL, Nguyen B, Artal A, Rosell R: Randomized phase III study of gemcitabine-cisplatin versus etoposide-cisplatin in the treatment of locally advanced or metastatic non-small-cell lung cancer. J Clin Oncol 1999, 17:12-18.

7. Chang AY, Kim K, Glick J, Anderson T, Karp D, Johnson D: Phase II study of taxol, merbarone, and piroxantrone in stage IV nonsmall cell lung cancer: The Eastern Cooperative Oncology Group results. I Natl Cancer Inst 1993, 85:388-394.

8. Murphy WK, Fossella FV, Winn RJ, Shin DM, Hynes HE, Gross HM, Davilla E, Leimert J, Dhingra H, Raber MN, et al:: Phase II study of taxol in patients with untreated advanced non-small cell lung cancer. J Natl Cancer Inst 1993, 85:384-388.

9. Miller KD, Sweeney CJ, Sledge GW Jr: Redefining the target: chemotherapeutics as antiangiogenics. J Clin Oncol 200I, 19:1195-1206

10. Schiller JH, Harrington D, Belani CP, Langer C, Sandler A, Krook J, Zhu J, Johnson DH, Eastern Cooperative Oncology Group: Comparison of four chemotherapy regimens for advanced nonsmall cell lung cancer. $N$ Engl J Med 2002, 346:92-98.

II. Go RS, Adjei AA: Review of the comparative pharmacology and clinical activity of cisplatin and carboplatin. J Clin Oncol 1999, I 7:409-422.

12. National Cancer Institute: Common Toxicity Criteria Bethesda: MD; 1988.

13. Miller $A B$, Hogestraeten $B$, Staquet $M$, Winkler A: Reporting results of cancer treatment. Cancer 198I, 47:207-2।4.

14. Kaplan EL, Meier P: Nonparametric estimation from incomplete observations. J Am Stat Assoc 1958, 53:457-48I.

15. Mantel N: Evaluation of survival data and two new rank order statistics arising in its consideration. Cancer Chemother Rep 1966, 50:163-I70.

16. Kelly K, Crowley J, Bunn PA, Presant CA, Grevstad PK, Moinpour CM, Ramsey SD, Wozniak AJ, Weiss GR, Moore DF, Israel VK, Livingston RB, Gandara DR: Randomized phase III trial of paclitaxel plus carboplatin versus vinorelbine plus cisplatin in the treatment of patients with advanced non-small-cell lung cancer: A Southwest Oncology Group Trial. J Clin Oncol 200I, 19:3210-3218

17. Alvarez A, Mickiewicz, Brosio C, Giglio R, Cinat G, Suarez A: Weekly taxol $(T)$ in patients who had relapsed or remained stable with $\mathbf{T}$ in a 21 day schedule. In Proceedings of the American Society of Clinical Oncology: 16-19 May 1998; California Edited by: Michael C. Perry: WB Saunders; 1998: 188a.

18. Akerley W: Paclitaxel in advanced non-small-cell lung cancer: An alternative high-dose weekly schedule. Chest 2000, I I 7(Suppl): I52-155.

19. Akerley W, Glantz M, Choy H, Rege V, Sambandam S, Joseph P, Yee $L$, Rodrigues $B$, Wingate $P$, Leone $L$ : Phase I trial of weekly paclitaxel in advanced lung cancer. I Clin Oncol 1998, 16:153-158.

20. Akerley W, Herndon J, Egorin MJ, Lyss AP, Kindler HL, Savarese DM, Sherman CA, Rosen DM, Hollis D, Ratain MJ, Green MR: Weekly, high dose paclitaxel in advanced lung carcinoma: A phase II study with pharmacokinetics by the Cancer and Leukemia Group B. Cancer 2003, 97:2480-2486.

21. Belani CP, Barstis J, Perry MC, La Rocca RV, Nattam SR, Rinaldi D, Clark R, Mills GM: Multicenter, randomized trial for IIIB or IV non-small-cell lung cancer using weekly paclitaxel and carboplatin followed by maintenance weekly paclitaxel or observation. J Clin Oncol 2003, 21:2933-2939.

22. Belani CP: Weekly paclitaxel and carboplatin in non-small cell lung cancer. Lung Cancer 2000:128-129.

23. Socinski MA, Schell MJ, Peterman A, Bakri K, Yates S, Gitten R, Unger P, Lee J, Lee JH, Tynan M, Moore M, Kies MS: Phase III trial comparing a defined duration of therapy versus continuous therapy followed by second-line therapy in advanced-stage IIIB/ IV non-small-cell lung cancer. I Clin Oncol 2002, 20: I335-I343

24. Smith IE, O'Brien MER, Talbot DC, Nicolson MC, Mansi JL, Hickish TF, Norton A, Ashley S: Duration of chemotherapy in advanced non-small-cell lung cancer: A randomized trial of three versus six courses of mitomycin, vinblastine, and cisplatin. J Clin Oncol 200I, 19:1336-1343.
25. Belani CP, Kearns CM, Zuhowski EG, Erkmen K, Hiponia D, Zacharski D, Engstrom C, Ramanathan RK, Capozzoli MJ, Aisner J, Egorin MJ: Phase I trial, including pharmacokinetic and pharmacodynamic correlations, of combination paclitaxel and carboplatin in patients with metastatic non-small-cell lung cancer. J Clin Oncol 1999, 17:676-684.

26. Kearns C, Egorin M: Considerations regarding the less-than expected thrombocytopenia encountered with combination paclitaxel/carboplatin chemotherapy. Semin Oncol 1997, 24(Suppl 2):91-96.

27. Belani CP: Paclitaxel and docetaxel combinations in non-small cell lung cancer. Chest 2000, II7(Suppl): I44-I5I.

\section{Pre-publication history}

The pre-publication history for this paper can be accessed here:

http://www.biomedcentral.com/1471-2407/5/10/prepub
Publish with Biomed Central and every scientist can read your work free of charge

"BioMed Central will be the most significant development for disseminating the results of biomedical research in our lifetime. "

Sir Paul Nurse, Cancer Research UK

Your research papers will be:

- available free of charge to the entire biomedical community

- peer reviewed and published immediately upon acceptance

- cited in PubMed and archived on PubMed Central

- yours - you keep the copyright 